\title{
Social Criticism in the Text Scripture of Dharmasonya
}

Komunitas: International Journal of Indonesian Society and Culture 9(1) (2017): 70-80

DOI:10.15294/komunitas.v9i1.8340 (C) 2017 Semarang State University, Indonesia p-ISSN 2086 - 5465 | e-ISSN 2460-7320 http://journal.unnes.ac.id/nju/index.php/komunitas

UNNES

JOURNALS

\author{
Aris Aryanto' ${ }^{1}$, Bani Sudardi ${ }^{2}$, Andrik Purwasito $^{2}$, Abdullah Wakit $^{2}$ \\ 'Universitas Muhammadiyah Purworejo, Cental Java, Indonesia \\ ${ }^{1,2}$ Cultural Studies Program, Universitas Sebelas Maret, Surakarta, Cental Java, Indonesia
}

Received: 28 December 2016; Accepted: 27 February 2017; Published: 30 March 2017

\begin{abstract}
This study took a closer look at the socio-condition of the Javanese people in Surakarta at the time Dharmasonya (Ds) text was produced through a perspective of critical-sociological studies. The present Ds text was read through seeing the historical life of the Islamic religion. The main objective of this study was to probe socio-cultural life of the society in the age the Ds text was produced. The data source used was the translation of Ds text by Suratmin which was issued by the Ministry of Education and Culture. To obtain the objectives, study on the Ds text was compared with other similar ancient texts of the same themes produced in the same time; these texts were Serat Wedhatama by KGPAA Mangkunegara IV (1853-1881) and Serat Tjemporet by R.Ng. Ranggwarsita. The data was analyzed through perspectives of Hermeneutic and Semiotics methods. The result shows that in Ds text, social criticism was an attempt to resist against the dynamic circumstances faced by the society at the time wherein the social status and nobility became people's life concern. Such circumstance has apparently been used at least by a stream of Islamic group to write religious text in literary form, since religious doctrine was considered as one of the powerful weapons to control the society. Thus, most people would forcefully obey and submit to the teachings of Islam based on the Sharia law.
\end{abstract}

\section{Keywords}

Dharmasonya text; social criticism; Javanese community

\section{INTRODUCTION}

Social criticism against the Dharmasonya (Ds) text as a literary work of the Javanese communities shall last without silence. Bearing in mind this literary work is a product of the society; then the background of people's lives became the source of inspiration, primarily in writing such masterpiece. Literature was necessarily a mirror of the people's lives in its age. By literature, social life can unfold its people. The main purpose of this article was to uncover the social systems that made up the Java community in Surakarta at that time. This study restricts its discussion only in Surakarta. The reason must be because the origin of the source Ds text was produced and found in Surakarta. Thus, this article will explain all sides of the Javanese community in Surakarta at the time the Ds text was produced.

Ds text is in the category of text piwulang genre. This genre of text recounts the pious, holly and wise persons' teachings that took its basic embodiment from the teaching of kejawen and integrated it with the Islamic teaching (syncretism) (Behrend,

\footnotetext{
Corresponding author

Jalan Ir. Sutami No. 36A, Central Java 57126, Indonesia

Phone: (0271) 646994

Email

aryanto.ariskrn@gmail.com; banisudardi@yahoo.co.id; andrikpurwasito@gmail.com²; abdullahwakit@yahoo.com²
} 
1990: ix). The object of this study is a transcribed and translated form of Ds by Suratmin from the Department of Indonesia Language Education and National Culture which is currently stored in the Library of Sasana Pustaka Kraton Surakarta. The Ds text was selected for it has been translated into Indonesian language. Ds text contains the teachings of Islamism. The Islamic values in the text concern the implementation of Sharia law. The author stated that anyone who would violate the law (Sharia) shall get severe punishment. It is further strictly said that those who perform the art of puppet show and dance were deemed to be the brother of Satan. This situation explains us that the Islamisation of Java was in conflict.

At this point, the serious problems addressed in the text were the puppet show and dances prohibited by reason for their unlawfulness. In contrary with the text itself, the real situation in current Javanese community is totally different; people up to now uphold the art performance traditionsas if the problem referred in the text has never been exist in today's Javanese community. In this case, the efforts of eliminating, freezing, and the annihilation of the local tradition were done at least since Ds was created. Taking a closer look at the Ds text, it really gave rise to a paradox ${ }^{1}$. On the one hand, the Ds text echoed a religious law that must be implemented. Clearly, it judges over the existence of Javanese culture. This type of resistance against the Javanese culture was likely to set out the agenda of propaganda.

The text production of Ds text remains debatable for it took its own stance against the essence of Islamic teaching as a collec-

1 The Ds textf at least raised a paradox because the text and context literally closed fro other interpretations and did not give space to any of the outside dialecti copportunities. Such imagery causes the integration between science and religion in the reflection of this text remained difficult to be achieved. The first text of Ds firmly rejects other things that appear outside the four main foundations of Islamic law (the Qur'an, Hadith, Qiyas and Ijma '). According to the Ds text, the knowledge raised apart from these four bases is considered to be from syetan and is of course considered heretical and misleading. tion of the reconciling doctrine. Standing as a tradition or religious teaching inspired from the textual sources that require interpretation, the consensus among the groups of Islam has never made any stream of religious teaching to be the authoritative force (Gumperli 2005, p.5). Hermeneutically Islamic text is a collection of free of interpretation text, however, Ds text has undergone transformation somewhat rigid form of belief, in which the intersection of spirituality and humanity became physically solid yet fragile in soul (Siradji 2013, p. 88). This is an effort on the cessation of Javanism tradition. Prosecution realized through radical act indicated in the Ds text according to historical records of Indonesia has never succeeded. The war of ideologies have led to certain conflicts, both ethnic and social conflict and even political.

Studies on the Javanese text literature have been done by researchers using different paradigms and approaches. Previously, a study of the Ds text carried out by Dharma Palguna and Wratsari Krishnamurty. However, with different types of literature and approach of studies, research on Dharma Palguna is in the form of papyrus writing entitled Dharmasunya, written in Old Javanese, anonymous, and in the form of kakawin (Old Javanese poetry). Similar studies was conducted by Frans Magnis Suseno on the ethics of Java (a philosophical analysis on the life wisdom in the Javanese text of Serat Wedatama). In addition, Javanese Ethics is a reflection of the inward and outward description of the Javanese people. It contains teachings and spiritual guidance, attitude of the Javanese to live interaction with life, with fellow humans, nature and God. It objectively stated that Humans are destined in harmony.

The previous studies tend to focus on highlighting the Islamic mysticism, Javanese wisdom and Javanism. Nearly all of them have not reached the critical studies. This study employed a critical postmodern paradigm. Through this paradigm, this hopefully reveals the social criticism and the background of the text at the time it was created. To observe the text from literary 
criticism perspective, one might put a question, why the author was intrigued to argue in that circumstance? Certainly there were unresolved problem behind the writing of Ds text. Thus, Ds text as a manifestation of the Javanese culture in writing form needs to be understood from the society's perspective at the time the text was composed. Knowledge of the various conventions of life behind the creation of Ds text has a major role in attempt to understand its whole contents. Sociology as a science that studies the society is applied to reveal the social system prevailing at the time Ds text was initially produced, namely by having deeper understanding into the people's lives through contemporary literature. Even though there seem to be speculative, but at least it will enable us to draw up an insight about the lives of the people behind the written literary work.

This study is under the paradigm of Cultural Studies which applied the descriptive qualitative method as its research design. Cultural Studies prefer qualitative methods since it focuses on the analysis of cultural meanings (Barker 2013, p. 29). The Qualitative research design helps the researcher in explaining various phenomena related to the object of the study in more depth and detailing. Additionally, this study also applied modern philology and intertextuality method as a step to disclosing and tracing back comprehensively the Ds text from the textual side. The data source of this study was the translation of Ds text by Suratmin which was issued by the Ministry of Education and Culture through the Indonesian and Regional Literature Book Publishing Project printed in Jakarta by Balai Pustaka in 1981. Ds text reflects the teaching and guidance into spiritual emptiness through sorts of obligations and prohibitions in a way to achieve perfection and the life's ultimate destination. The discussed text of Ds was in the forms of tembang macapat (recited Javanese poetry) ${ }^{2}$. To obtain the result of objectives of

2 The data comprising of: Dhandhanggula 24 verses, 49 verses Li, Asmaradana 53 verses, Pangkur 25 verses, Sinom 37 verses, Dhandhanggula 51 verse, Kinanthi 30-verse Sinom 31-verses, Pocung this study, the Ds text is compared with other similar ancient texts of the same themes produced in its time; these texts are Serat Wedhatama by KGPAA Mangkunegara IV (1853-1881) and Serat Tjemporet by R.Ng. Ranggwarsita. The data analysis techniques applied were Hermeneutic and Semiotics methods of analysis. In this case, the researcher views the Ds text as a discourse object that reflects a system of linguistic sign. To understand the contents of Ds text, he carefullty reads the signs to fully understand the meanings underlying the text.

\section{Serat Dharmasonya}

The dharmasunya text was written in Old Javanese of papyrus form that reflects the teachings on how to enter the realm of sunya (silent/vacancy) toward the relationship with God according to the Hinduism tradition (mystical behavior). The study conducted by Dharma Palguna applied philological method. In short, the dharmasunya text recounts story of a spiritual journey (holy) a Kawi-wiku person named Kalamanatha going into the sources of pure water (tirthayatra) through understanding. According to tradition, the water is not only used as a means of purifying but also as a symbol for purity itself. The essential teaching of Ds text reflects the search for spiritual enlighment from self-awareness in seeking for emptiness. The deeper someone into his/her search, the empty and vanish he/she is (inner detachment). To seek for eliminating; this means that to seek until unable to find, disappear that one does that would never realize that he/she is in lost. "If successful at eliminating the road, people will no longer feel lost (hana hilang tan ina$k u$ ). If one successful with the search, he/ she will no longer feel arrived or found (the destination)" (Palguna 1999, p. 125). The ascent on the road with empty void enables a person to essentially feel in which that emp-

50-verses, Dhandhanggula 40 verses, Kinanthi 36-verses, Asmaradana 27-verses, Sinom 42 verses, Durma 18-verses, Dhandanggula 28 verses, Sinom 15-verses, Mijil 47 verses, Dhandhanggula 36-verse, Sinom 26-verses, Pangkur 48-verses Durma 33 verses. 
tiness is the God.

The given name of Kawi and the Wiku were not just a predicate, but these reflect a consequence for overall the storytelling. There is a convention followed when the author speaks as Kawi and likewise if speaking as Wiku. As a Kawi, he voiced the desire to experience beauty. The magnitude of yearning led him to negate his own existence. As a wiku, he apparently demanded by tradition to voice what was institutionalized as the correct one. Therefore, discourse of a Wiku is didactic on an authority that it is difficult to determine when he spoke as Kawi and when as Wiku. Thus, those two words, namely kawi wiku are the terms that are explainable as a discourse appears in Ds text.

\section{Critical Review towards the Javanese Text}

In the journey, the Ds text written in Islamic version came into existence and which becomes the object of this study. The comparisson of both texts, the Islamic version and the Old Javanese one in Hinduism version, the two of texts periods are quite in distant. In addition, the Islamic version does not inform any name of the author (anonymous) and is in macapat poetic prose form. However, if it is seen from the contents, the author presumably belonged to one of the Islamic streams called Sufism, since the dominant teachings in the text recount the Islamic spiritual journey. Based on the acculturation of Javanese culture, Islamic teaching inspires the principle of Javanese mystical journey which integrates four levels of spiritual search. The Javanese spiritual journey described by Hadiwijono (1967, p. 94-115) departs from the outward condition, starting from the most rugged parts of the body towards the most delicate things, this belief is in the category of mystical Islam (Sufism) Simuh 1988, p. 255-269).This indicates: (1) the current text of Ds is categorized as a form of thinking contestation or kapujanggan; (2) the popularity of Ds title itself 3 (3) Ds text

3 As a spiritual text, Ds also explain the position of God and man. The explanation is very popular in the community of Central Java and East Java in particular, often by analogy with the model of version of Islam was created because there is an agreement regarding the use of the same concept of God. As many found within the text reference of God's name with the word of Allah and Hyang Widdhi, Hyang Agung, Hyang Suksma, Hyang Mulya were simultaneously used. Meanwhile in Islam, the God's name is only denoted with a unique name called Allah. Thus, from the foregoing description it is clearly visible the difference between this study from the previous studies that have been done to Dharmasunya text (Palmyra form) written in the Old Javanese.

Another study on Ds text has been done by Wratsari Krishnamurty. Krishnamurty Wratsari research was object in the form of text entitled Dharma Sonya gancaran (prose). The text of Dharma Sonya was written by Yogiswara in 1821. The theoretical basis employed in the study of that $\mathrm{Se}$ rat (text) was the Semiotics along with the modern method of philology. The method employed is descriptive qualitative and hermeneutic methods. Text of Sonya Darma contains the origin of the world or a breakdown by five types of realms namely: the realm of Sonya Ruri, the realm of Tirta Yoga, Kerta Yoga, Yoga Dyapara and the realm of ParamaYoga.

Taking the Old Javanese textual corpus into consideration in the study of Islam on Java has gained some currency. Studies that do this include the works by Simuh (1988) and Woodward (1989). Woodward (1989) found the difficulty in tracing the Hindu/ Buddhist elements of ideologies and ritual modalities in Muslim community of Java. The religious practices allegedly embrace the Hinduistic ceremonies, such as Grebeg Mulud at the Yogyakarta court. The Javanese beliefs and practices manifest in the life of the Javanese life view, including many things that Geertz (1960) claims as necessarily the practice of syncretism. Another study was conducted by P.J. Zoetmulder on Manung-

puppet show, although the latter analogy is rejected by some researchers. The refusal because of the worriness toward public schools of fatalism that does not comply with the principle of religious teachings. The fatalism ideology of "manunggaling kawula-Gusti” (God unites with His creature) conceived reckless. 
galing Kawula Gusti 'the Islamic mysticism'. The object of Zoetmulder's study was Sastra Suluk of Java and some proportions of Serat 'text' Centhini. Zoetmulder's study discussed the human being's relationship in contemplation to the existence of God in reaching the stage of enlightenment that is the unity between I and the Gusti (God). In the realm of culture, that sort of thing is called Sufism. That is, the end of man is to go back (home) to the Lord.

Furthermore, to return home (mulih) here does not only require narrow sense of interpretation, which was the return and meet the God, but even more than that. Human purpose in life is to find their own identity, searching for the truth life purpose on earth (sangkan paraning dumadi), which ultimately to seek and find the existence of God. In Javanese mysticism literary works, there were reflected efforts in seeking and finding the God through the experiences of human life (the Sufis). In addition, the Javanese mysticism literature is part of the religious literature. Although both current and previous studies discussed the IslamicJavanism mystical literature, however, Zoetmulder concerned much about the level of mystique, while this study shall explain the Ds text in terms of its social criticism. The beginning of the analysis may still necessarily borrow the Zoetmulder's model. The Javanese are quite associated with the mystical practice. Arnold van Gennep (1960) studied the Javanese ritual activities and wrote a book entitled "the Rites of Passage" purposed the theories of rites shift and the enactment ceremony. He elaborated philosophically phases of ritual. The first phase separation, the second phase is transition/ merge, and the third phase is aggregation. $\mathrm{He}$ (1960) further argued individuals within a society are in ambiguous; he is in a jammed position between order and disorder, so called luminal phase. Liminality phase society needs to continually defined themselves in facing the stilted structured community which make them as if a mechanical entity.

Damardjati Supadjar's (2001) Social Philosophy studied the text of Serat Sastra
Gendhing, a literary work contains the teachings of social philosophy. Damardjati focused on the Islamic-Javanese mystical problem in that text. His study revealed that there has been an acculturation between the teachings of Islam with Javanese belief. The condition is shown through the verses of Serat Sastra Gendhing which has been widely incorporated sense of Islamic belief that can be seen though the language used is still little known in its time. This is because Islamic teachings remains quite strongly embedded Kejawen 'Javanism' because at that time Islam has not been fully embraced by the Java community.

Serat Sastra Gendhing,a type of literary work written by Sultan Agung, is one of the Javanese texts that recounts spiritual guidance to human beings in order to fully aware him/herself and that additionally enable them to 'unite' with God (pamoring kawula Gusti). Islamic mysticism is widely known as Sufism. Damardjati further concluded that the mystic is the understanding of the parable to the knowledge of manunggaling kawula-Gusti, in which conceptually between man and the God are inseparable, indivisible and fused into one. The study conducted by Damardjati is limited only on aspect of the Javanese mystical behavior.

\section{Darmasonya Text as the Social Criti- cism in its Age}

Literary works from time to time need to be treated in accordance with the times. Every literary text is read and should be read in continuance with the background of other text; there has never been a text that truly independent, in the sense that the text production and reading shall never be possibly done without the existence of other text as exemplary or skeleton (Kristeva in Teeuw, 2003: 120). It means that the understanding of a new text requires background knowledge of the other similar text that preceded it. It indicates that a literary work is not created in a vacuum culture. A work of literature will die, dry and stagnant if not revived by readers in the next era.

In the early era of the Surakarta region and civilization, religious texts such as Ds 
and several similar texts remained difficult to digest by the Javanese community of the day, thus the dialectic interpretation on the highlighted concern was only viewed either one-sided. Even the text of Ds positions itself seemed to be finally defined. Presumably in such a case the Ds text writer considered that the royal community of Surakarta at that time had already a mature religious form of belief. The following explains segments of the Ds text that highlight social criticism of its age.

\section{Prohibition of Spending Money for Wasteful life}

The Ds text in essence contains social criticism of the Javanese lifestyle in its time. In pupuh or 'stanza' of Durma, the second stanza writing described as follows:

\section{Sayektine wong mukadiraken arta//sana- ke setan ugi//ywa mukadir sira//maring ing artanira//aja sira nginum awis//aja badhayan//aja wayangan malih. \\ Literal translation: \\ Surely those who squandered the money, are those who would become the brot- hers of Satan, do not waste money, do not drink, do not perform a dance nor the puppet shadow show.}

The text verse of Ds contains the prohibition of spending money for drugs (to live life of drunkenness), staging a dance, and performing puppet shadow show. Apart from this, this is an evident that there was a strong opposition against the former lifestyle of Javanese communities. In addition, these quotes give a clear picture of prosperous life in the Javanese community. But it is in the contrary with the real spiritual life practiced by the society. In fact, the society seems to inevitably confront with moral decadence and spiritual shallowness. This can be seen from the fact that people like to drinking liquor or drugs and spending money for such wasteful life activities that are beyond the values of Javanese culture. Staging puppet art and dance were no longer a way of life but has metamorphosed into a sexual desire commodity. Thus, a pheno- menon that appears in today's society, the dancers and sindhen (female singers in the puppet show) is quite often associated with mistress or the commercial sex workers in disguise. Women are no longer judged by the good performance but must be more to look beautiful, seductive, daring in terms the way they dress and makeup.

\section{Prohibition of Staging Art Performanc- es}

Under the influence of changes in the life orientation of the Javanese society, there emerging negative stigma on the art of puppet show and dance. Thus, it is not surprising that staging (nanggap) the puppet shadow show and dance were rejected because people who conduct and practice them were misguided from the religious teachings.

\begin{abstract}
[...... sapa kaliwatan wayang latarira yen nora maca nuli ing tangawud pan ilang amalira lawase catur dasa ri, tan tinarima ngamale ing Hyang Widhi//aja siya-siya sira marang arta, dak dok angungelken bedhil pan eman-eman..."
\end{abstract}

Literal translation:

for those whose house passed by set of puppets and did not immediately read ta'awud, the reward will be lost for forty days, not accepted by God as charity. Do not spend your money for useless things, unfortunately.

Even in the verse of Durma it is mentioned that in the hereinafter everyone who his/her driveway was passed by puppet troupe, the forty days charity and good deeds of him/her shall be lost instantly. This statement clearly stated that the lifestyle of the community in which the Dhrmasonya written implied a great religious crisis, that is, people like to drink intoxicating beverages, stage dance and puppet shadow shows for nothing more than just a desires commodity.

The text explicitly teaches frugal lifestyle. On the other hand, the text experiences a cultural clash with the script of writer making his own dogma that when puppet passes their house the reward will be lost for 
forty days. Please note that a puppet show in the Java community has become a way of life that brings a set of values. Puppet show has also been developed into a medium for promoting a variety of interests. Strictly speaking, the effect of striptease dangdut performances definitely is not better than the puppet show.

It is interesting in the Ds text when puppet show was being rejected, Ds text never questioned the name of Hyang Suksma, Hyang Widhi instead of Allah. Thus, there really was no sentimental name for God in the Ds text. Thus, it becomes clear that the dogmatic thought explained in the text was not only for religious purposes, but also for political and economic objectives. In the realm of cultural studies, the text should be read wisely and differently. First, the author of Ds shows their work to the low economy class society under the Dutch colonial period. Second, the author of Ds lives in the low economy class community, so that his work reflects the economic disparities between the bourgeoisie and the lower classes (the underprivileged). Third, the author of Ds gets the doctrine from their predecessors or teachers. To explore these issues clearly, it is required a special study which focuses on historiography matter on the Ds text manuscript.

On the other hand, the reality is so much ironical to the Javanese people who have never forgotten their traditions. Ritualistic events, such as ruwatan, selametan, nyadran, haul, yasinan, tahlilan, grebeg are the heritages of the Javanese traditions from which the religious teaching such as Islam was integrated with the local culture, and such events have been preserved to this day. Through practicing such integrated customs in the form of traditions, local rituals like ruwatan, slametan and others were actually more visible stance of the people's religiosity.

\section{Overviewing the Dharmasonya Text}

The name of Darmasonya in the Javanese literature appears twice in two texts of different periods (Poerbatjaraka 1957,p. 51, 138). The first name of Ds initially appeared at the entry in the pale group of Old Javanese literary period, while the second Ds name appeared in the early age of Surakarta. Ds text is currently stored in the library of Sasana Pustaka Kraton, Surakarta court with the text catalog number 72 Ds, Ha SMP - KS = 105 in text form with the copy number M: S sp no.26.72 ha-122 ms. The Ds text has been being circulated in the society in the book of translation by Suratmin from the National Education and Culture Department of Indonesia as the procurement books and the local Indonesian Literature in 1981, published by Balai Pustaka.

Other Ds text are stored in the library of Reksa Pustaka Mangkunegaran in the form of two text of Ds with specific code; MN A29 (SMP 67/4) and MN 319D.7 A196 (SMP 204/1). MN text with code A 29 (SMP 67/4) was written by Raden Ngabehi Yasadipura II or RT Sastranagara (1756-1844) under the name of Serat Dharma Sunya in Surakarta in 1815 . Serat Dharma Sunya according to the local script catalog of Mangkunegaran is classified as knowledge or kawruh about rahsa. Text with code MN 319D.7 A196 (SMP 204/1) is inscribed with the name Serat Darma Sonya / Pustaka Darywa / Widdya Pramana. Its author is anonymous, written in the mid-19 ${ }^{\text {th }}$ century Surakarta. The text was edited by Ngabehi Wirasuwignya. According to the local script catalog of Mangkunegaran, the text contains the Javanese mysticism.

The Ds text written in Old Javanese language has existed since the 14th century, the same period of the Buddhist religious scriptures of Shiva was written. In the present level of reality, Ds text places an important position as the holly book of Shiva for Buddhist adherents in Bali. Ds text in the form of kakawin and the anonymous author of Ds text written in the Old Javanese language recount story of the spiritual (holy) journey of a Kawi-wiku named Kalamanatha who went to the sources of pure water (tirthayatra) through understanding (Palguna 1999, p. 6).

Darmasonya text written in Old Javanese language in the form of poetical song or kakawin has been rewritten by many copyists. Thus, it is not surprising that it ap- 
pears in different variants. This gives the initial assumptions about the popularity of the text. Additionally, there ultimately comes an allegation that the old text of Ds played a great influence on the later text writing that resulted to literary impacts on the production of Ds text. As a result, there exist some of the later Ds text among others were the Ds Keling and Dharma Putus. Thus, if we wish to trace back its origin in Surakarta, it approximately has existed since 1800 to the mid19 th century or around 1850 . Poerbatjaraka confirmed such information in his book of Kapustakan Djawi (1957, pp, 2, 128) that the Javanese literature evolved from Sailendra Era to the era of Early Surakarta around the 800 s to 700 .

\section{The Lifestyles of Javanese Society in Surakarta}

According to the study that has been done by Darsiti Soeratman (1989, p. 1-2), the presence of residents in the year 1755 have brought new changes to Javanese people's living in Surakarta. The advent of new Western-style buildings and the fact that Surakarta become capital regency increasingly affected the changes in lifestyle of the Javanese community in Surakarta from the traditional to westernized. In addition, the increase in the economic condition of the community was supported by markets as a new source of livelihood for the people of Surakarta. Among the traditional markets were Pasar Gede, Pasar Kliwon, Pasar Pon, and Pasar Legi. With the present increasing economic society, this has consequently led the people to fond of holding (what the Javanese called nanggap) dance and puppets performance events.

Since 1746 , the indigenous religion of the majority of people in Surakarta is the Islamic syncretism religion with the local religion called Kejawen 'Javanism' (Soeratno 1989, p. 99). The Islamic religion was able to adapt with the indigenous mixed with beliefs and concepts of Hindu-Buddhist, type of beliefs which inclined towards believing mysticism. This can be explained from the concept of God as addressed in the Ds text. The word of Allah and Hyang Whidi used throughout the text ha similarities both in terminological and conceptual perspective of the God.

The development of Javanese culture was actually enriched, adapted and integrated to the elements of the Islamic religion at the reign of Pakubowono III (1749-1788). Thus, Ds text, especially in its poetic stanza reflects the social criticism at the age. The phenomenon that occurred amidst the society at the time was mostly captured by the author, in which the people were considered to have gone far strayed from the teachings of Islam. The arts of puppet and dance were prohibited because it is religiously viewed as harming the people's belief and directed them toward lust. Though, in that sense, the teachings taught from the text were apparently originated from one stream of the Islamic radicalism. The Islamic Javanism as living up by Javanese Moslems today has been practiced for centuries if we wish to review of how was the method used by the Islamic preachers (Wali) long ago until Islam successfully took over the Java Island.

In that case, religion serves to provide direction towards meanings and offers an explanation of the events and experiences which deviates from tradition. Geertz sees religious system of symbols can be elaborated to many ways. Javanese people are traditionally adaptable and have a high integrity, respectful and appreciate human values of various beliefs, additionally Javanese people stay consistent with their view of life. On the contrary to the view of religious people, being accommodative and tolerant to the local culture, on the one hand, is considered to be negative, because it sometimes literally incorporated the localism to Islamic belief. But it does have a positive impact too, syncretism should be as an important aspect, it is a crossing bridge for Islam to be accepted as a new belief by the Javanese community.

Social system embraced by people of Surakarta Palace in 1830 concern with social and hierarchical positions such as leadership (king), nobles, courtiers, attendants, and servants (Soeratno 1989, p. 8). The contextual circumstance of the text approved the social condition at that time, wherein 
the kings, noble people, and gentries were maintaining their positions and statuses. The extravagant lifestyles of the nobles and the kings in the past were realized in the attitudes of spending money for nothing but lead to the increase of the regional expenditure, the overwhelming wedding customs, having wasteful times, etc. In addition, a regulation issued by the Governor-General Van der Capellen (1818-1826) on the prohibition of leasing the land to the entrepreneurs of Europe and China made the kings and nobles more and more indebted. It is clear that the lifestyle of the kings and nobles much or were influenced by the lifestyle of the colonial people in Surakarta. There are indications that the model is practiced by the colonial to perpetuate its power in Java.

The ins and outs of the Javanese community in Surakarta can also be traced out from Ds text. This lies under the assumption that the literary works come into existence as a reflection of the situation at the time. Although in the present context, some of the existing literatures are only deemed as sort of imaginative works of the writers.

\section{Intertextuality of Ds versus Other Similar Texts in the Age}

As has been elaborated in the method section, the secondary data source of this study uses similar texts related to the object of this study. Similar texts were used as comparative data and supporting ideas on the criticism of Ds text. This aimed at revealing and explaining the position of the Ds text in the context of Islamic teachings in terms of the ideological and resistance aspects.

The paradigm of intertextuality as purposed by Julia Kristeva whose study arouse from the further development of Mikhail Bakhtin's thought of dialogue (dialogism). Bakhtin sees that the meaning of a text lies in the internal relations within the text itself, which is in opposition to external signaling relations. Dialogism is an autonomous way out of the text alienation from society and self-references (Piliang, 2003: 121122). Additionally Kristeva (1980) develops Bakhtin's dialogue into an intertextual paradigm to explain the relationships between one text to another.

The Darmasonya text as a result of the Javanese writing culture needs to be understood on the context of the society that gave birth to that text. Knowledge of the various community life conventions behind the creation of Darmasonya texts has a great role to probe understanding of the written contents , one of which is by digging deeper into the life of the community through the contemporary literary works through intertextual approach, it is a way of reading text through another similar texts. Literary works present as a reflection of the timesalthough in the contemporary context, some existing literary works merely played a role as as works produced on bases of imaginative thoughts of the writers.

Serat Wedhatama, a literary work by KGPAA Mangkunegara IV (1853-1881) (Any 1983 , p. 5) in general contains the guidance or instructions and noble advice for man to achieve worldly and hereafter happiness. It is written in Serat Wedhatama in one of the poetic song of Gambuh;

Samengko ingsun tutur//sembah catur supaya lumuntur//dhihin raga cipta jiwa rasa kaki//ing kono lamun tinemu//tandha nugrahaning Manon.

Literal translation: next time I would tell (you)// of four worships to follow; the first is body, creation, soul and sense, O..my son // that's where will you find// verily it is a sign for the greatness of the God.

The above excerpt describes four worship (read: the embodiment of the attitude to carrying out all the God's commands and staying away from all of His prohibitions) as should be done by a human being, in case she/he wishes for the happiness of the world and the hereafter, namely bodily worship, worship of the creation, worship of the soul, and worship with rasa (intuition). In this case, the author of the text Serat Wedhatama would realize the social circumstances of the people living at its age wherein the religious people and their beliefs experienced shallowness that that would further triggered spiritual decadence. Youth in particular had been following their own lusts and sin- 
ful attitudes. Therefore, the author of Wedhatama text directs people to do goodness in order to live happiness life in the hereafter. It is written in the following excerpt in the poetic song of Pocung.

Ngelmu iku kalakone kanthi laku//lekase lawan kas//tegese kas nyantosani//setya budya pangekese dur angkara.

Angkara gung neng angga anggung gumulung//gegolonganira//triloka lekere kongsi//yen den umbar ambabar dadi rubeda.

...Yeku patut tinulad tulad tinurut//sapituduhira//aja kaya jaman mangkin//keh pra mudha mundhi dhiri rapal makna.

Durung pecus kesusu kaselak besus// amaknani rapal//kaya sayid weton $\mathrm{Me}$ sir//pendhak pendhak angendhak gunaning janma.

Literal translation: Science is obtainable if it is pursued with the intention of seeking// beginning with firm intentions, verily sincerity can destroy anger and evil. Savage lust gathered into one // groups of lust // going to three worlds//will be dangerous if they left aside. That's the worth embodiment and followed all the instructions // do not act like people of today, many young people are bragging. Not clever but counterfeiting like a clever // describes prayer // look like the people from Egypt // love to underestimate the abilities of others.

Serat Tjemporet by R. Ng. Ranggawarsita written in 1799 also implied the Javanese society at the time. Despite using background of fairy tale which was drawn from the final section of the Pustaka Rajaweda (Hadisutjipto 1987, p.9), it explicitly outlined the life conditions of the people, especially those who are surrounding the king. Text or Serat Tjemporet contains about the life of kings in Bagelen, Prambanan, Purwacarita, Pagebangan, and Jepara. The names of the characters in the story are actually figurative names that are deliberately engendered by Ranggawarsita. Ranggawarsita is widely recognized as a writer who, especially highlights the critical-social problems that can be found in several of his works, such as Serat Kalatidha or better known as jaman edannya 'its crazy time'. Serat Tjemporet if further understood was the criticism over the life of the king at that time. Every king hold different character. This is why lives of the society are also dependent on the ruling king.

Last but not least, as a reminder to readers of Ds text, the Javanese people have been traditionally adaptable and have a high integrity, respectful and appreciate human values of various beliefs. For whatever radical religious that has tried to change the life view of Javanese people, they would stay consistent with their own journey in truth seeking. The Ds text narrated the view that is against localism. Since in the view of religious people, being accommodative and tolerant to the local culture, on the one hand, is considered to be negative, because it sometimes literally incorporated the localism to Islamic belief. But syncretism does have a positive impact too, it is a crossing bridge for Islam to be accepted as a new belief by the Javanese community.

\section{CONCLUSION}

The social systems in which most of the Javanese community subjugated to at the time the Ds text was produced was relatively different in one to another region. In the Ds, there is a raised tension between culture and religion. Ds text shows the existence of an Islamic ideology in an extreme sense, in which the art of Wayang 'puppet shadow show' and dance were deemed to unlawful and thus prohibited. This is precisely inversely with the view of Islam in Java Island which positioned the existence of Wayang as an effective medium in preaching the Islamic doctrine to the Javanese society.

In Ds text, the social criticism was an attempt to resist against the dynamic circumstances faced by the society at the time wherein the social status and nobility became the people's life concern. This circumstance motivated at least a stream of Islamic group to write religious text in literary form, since religious doctrine was considered as one of the powerful weapons to control the society. Thus, most people would forcefully 
obey and submit to the teachings of Islam based on the Sharia law.

\section{REFERENCES}

Abdullah, S., 2012. Art criticism versus art writing: the Malaysian situation. KEMANUSIAAN, 19(2), pp. 63-78.

Any, A., 1983. Menyingkap Serat Wedotomo. Aneka Ilmu, Semarang.

Bardzell, J., Bolter, J., \& Löwgren, J., 2010. Interaction criticism: three readings of an interaction design, and what they get us. Interactions, $17(2)$, pp. 32-37.

Bauman, Z. 2011. Migration and identities in the globalized world. Philosophy \& Social Criticism, 37(4), pp. 425-435.

Behrend, T.E., 1990. Katalog Induk Naskah-baskah Nusantara Museum Sonobudaya Jilid 1. Djambatan, Jakarta.

Capra, F., 2009. The Hidden Connection. Jalasutra, Yogyakarta.

Cunha, M., \& Paiva, M. J., 2012. Text Anxiety in Adolescents: The role of self-criticism and acceptance and mindfulness skills. The Spanish Journal of Psychology, 15(2), pp. 533-543.

Damardjati, S., 2001. Filsafat Sosial Serat Sastra Gending. Fajar Pustaka Baru, Yogyakarta.

Darmasonya. 1981. A translated text into Indonesian by Suratmin. Balai Pustaka bekerjasama dengan Depertemen Pendidikan dan Kebudayaan, Jakarta.

Forst, R., 2011. The ground of critique: On the concept of human dignity in social orders of justification. Philosophy \& Social Criticism, 37(9), pp. 965-976.

Geertz, C., 1960. The Religion of Java. Free Press, Glencoe.

Gennep, A.V., 1960. The rites of passage, translated by Monika B Visedom Gabrielle L. Caffee. Routledge and Kegan Paul, London.

Gillespie, R., 2012. The art of criticism in the age of interactive technology: Critics, participatory culture, and the avant-garde. International Journal of Communication, 6, pp. 20.

Goldin, P. R., Ziv, M., Jazaieri, H., Weeks, J., Heimberg, R. G., \& Gross, J. J., 2014. Impact of cognitivebehavioral therapy for social anxiety disorder on the neural bases of emotional reactivity to and regulation of social evaluation. Behaviour research and therapy, 62, pp. 97-106.

Gross, A. G., 2012. The public sphere and rhetorical criticism: A cautionary tale. Argumentation and Advocacy, 49(2), pp. 141-144.

Gumperli, P., 2005. Islam and Peace-Interpretation/ exegesis of religious sources Vordiplomarbeit. GRIN Verlag, German.

Hadisutjipto, S.Z., 1987. Serat Cemporet karya R. NG. Ranggawarsita. Balai Pustaka, Jakarta.

Hadiwijono, H., 1967. Man in the present Javanese Mysticism. Bosch \& Keuning N.V., Netherland.

Kats, A., 200o. Postmodernism and The Politics of Culture.Westview Press, USA.

Kihlström, A., 2012. Luhmann's system theory in social work: Criticism and reflections. Journal of social work, 12(3), pp. 287-299.

Kristeva, J., 1980. Desire in Language : a semiotic approach to literature and art (diterjemahkan oleh Thomas Gora, Alice Jardine, dan Leon S. Roudiez). Columbia University Press, New York.

Latifi, Y. N., 2008. Kajian Kesusastraan Arab di Era Postmodernisme. Jurnal Penelitian Agama, 17(3).

McHoul, A., \& Grace, W., 2002. A Foucault Primer: Discourse, Power, and The Subject. Taylor \& Francis, Routledge.

Palmer, A., 2011. Social minds in fiction and criticism. Style, 45(2), pp. 196-240.

Piliang, Y. A., 2003. Hipersemiotika: Tafsir Cultural Studies atas Matinya Makna. Jala Sutra, Yogyakarta.

Piliang, Y.A., 2004. Posrealitas: Realitas Kebudayaan dalam Era Posmetafisika. Jala Sutra, Yogyakarta.

Simuh. 1988. Mistik Islam Kejawen Raden Ngabehi Ranggawarsita. University of Indonesia Press, Jakarta.

Soeratman, D., 1989. Kehidupan Dunia Kraton Surakarta 1830-1939. Taman Siswa, Yogyakarta.

Sugiharto, B., 2008. Javanese Epistemology. Journal Melintas, (24)3, pp. 369-384.

Teeuw, A., 1994. Indonesia Antara Kelisanan dan Keberaksaraan. Pustaka Jaya, Jakarta.

Turner, B., 2008. Teori-Teori Sosiologi : modernitas dan Postmodernitas. Pustaka Pelajar, Yogyakarta.

Woodward, M.R., 1989. Islam in Java: Normative Piety and Mysticism in the Sultanate of Yogyakarta. The University of Arizona Press, Tucson.

Young-Bruehl, E., 2011. Psychoanalysis and social democracy: A tale of two developments. Contemporary Psychoanalysis, 47(2), pp. 179-203.

Zhong-wang, L. I. U. 2010. The Dual Logic of Political and Popular Dimension-—On Criticism Boom of Chinese Martial Arts Novels in the 1930s. Journal of Southwest University (Social Sciences Edition), 1(1), pp. 1-12. 